Article

\title{
Effects of Soil and Water Conservation Measures on Runoff and Sediment Yield in Red Soil Slope Farmland under Natural Rainfall
}

\author{
Xiaoan Chen ${ }^{1,2}$, Ziwei Liang ${ }^{3}$, Zhanyu Zhang ${ }^{1, *}$ and Long Zhang ${ }^{2}$ \\ 1 College of Agricultural Science and Engineering, Hohai University, Nanjing 210098, China; \\ onlycxa1@sohu.com \\ 2 Jiangxi Institute of Soil and Water Conservation, Jiangxi Provincial Key Laboratory of Soil Erosion and \\ Prevention, Nanchang 330029, China; 13576909451@139.com \\ 3 College of Water Conservancy and Hydropower Engineering, Hohai University, Nanjing 210098, China; \\ ziweil@hhu.edu.cn \\ * Correspondence: zhanyu@hhu.edu.cn
}

Received: 20 March 2020; Accepted: 15 April 2020; Published: 22 April 2020

\begin{abstract}
This paper analyzes the relationship between runoff, soil erosion, sediment particles, and natural rainfall characteristics on sloping farmland in the red soil region of southern China. The surface runoff and soil loss data were measured on runoff plots during 66 natural rainfall events from 2015 to 2018 in Jiangxi Province. The results show that the maximum 30-min rainfall intensity $\left(\mathrm{I}_{30}\right)$ is positively related to the runoff depth, soil erosion modulus, and sediment mean weight diameter (MWD). With the increase in $\mathrm{I}_{30}$ during rainfall, the coarse sand content increases, and the fine sand content decreases. The average annual runoff of slope tillage, hedgerows with slope tillage, straw mulching with conventional tillage, and contour tillage decreased by $32.56 \%, 65.87 \%, 83.99 \%$, and $87.30 \%$, respectively, compared with that of bare land. Soil and water conservation measures can significantly reduce slope runoff. The flow-reduction effect of contour tillage and straw mulching with conventional tillage increases as $\mathrm{I}_{30}$ increases, and the flow-reduction effect of hedgerows with slope tillage first increases and then decreases as $\mathrm{I}_{30}$ increases. The coefficients of variation and standard deviations of the flow-reduction effects of different soil and water conservation measures decrease with increasing $\mathrm{I}_{30}$. The average annual soil erosion moduli of slope tillage, hedgerows with slope tillage, contour tillage, and straw mulching with conventional tillage decreased by $59.33 \%, 91.29 \%, 97.17 \%$, and $98.45 \%$, respectively, compared with that of bare land. Soil and water conservation measures can significantly reduce the sediment yield on slopes. The flow-reduction effects of hedgerows with slope tillage, contour tillage, and straw mulching with conventional tillage all increase with $\mathrm{I}_{30}$, and their coefficients of variation and standard deviations decrease with $\mathrm{I}_{30}$. The average single rainfall erosion sediment MWD of decreased by $5.91 \%, 8.33 \%, 9.69 \%$, and $13.32 \%$, respectively, compared with that of bare land. Straw mulching with conventional tillage can significantly reduce the MWD of erosion sediment, effectively reduce the content of coarse sand, and increase the content of fine sand. Straw mulching with conventional tillage is a very good soil and water conservation measure for sloping farmland. It not only has the best effect on reducing flow and sediment, but also can effectively intercept coarse sand and reduce the MWD of erosion sediment.
\end{abstract}

Keywords: sloping farmland; runoff and sediment; sediment particles; soil and water conservation measures; maximum 30-min rainfall intensity 


\section{Introduction}

Accelerated soil erosion has been an enduring problem since agriculture began, and is considered one of the major threats to soil ecosystem services [1,2]. Soil erosion is a serious problem in a variety of climatic areas, but especially in the semi-arid and semi-humid areas of the world [3], such as Europe [4], central Asia [5], and China [6]. Soil and water loss degrades the soil, causing serious problems for sustainable agriculture and the environment due to regional deposition outside the source site $[7,8]$, which directly affects sustainable land use. Red soil is a kind of soil developed in subtropical dry and wet seasons, with distinct areas and well-drained terrain. This soil can form from iron-rich sediments or the compounds may develop in the soil as it weathers; it contains more iron and aluminum oxides, and has a coarse texture, low fertility, and strong acidity. Red soil is widely distributed all over the world, such as at low latitudes in Africa, Asia, and Oceania, and is common in tropical rainforest areas; it is also present in Europe, especially on the eastern coast of the Mediterranean Sea and the Balkans [9]. The total land area of the red soil hilly area is $118 \times 104 \mathrm{~km}^{2}$ in southern China, approximately $12.3 \%$ of the total land area [10]. The existing cultivated land area in the red soil area of southern China is about $40.26 \mathrm{~km}^{2}$, accounting for $35.39 \%$ of the total land area of the region, of which dry land accounts for about $68 \%$ and paddy fields account for $38 \%$ [11]. The average annual rainfall in this area is between 800 and $2500 \mathrm{~mm}$, which is 1.9 to 2.8 times the average value of China [12]. Due to the large annual average rainfall and destructive human activities, the area has become one of the most extensively and severely damaged areas in China. Sloping croplands are an important arable land resource in China. The sloping croplands are also the main source of a large amount of the sediment in rivers, accounting for $6.7 \%$ of the total soil erosion in the country [12]. Rainfall on the slope causes rain and runoff to destroy the soil structure, resulting in the separation, handling, and deposition of soil particles [13].

Erosive rainfall, runoff, and sand production provide important energy and carriers for soil water erosion, which is a necessary condition for soil water erosion. There are many factors affecting soil water erosion, including soil condition, topography, land use/vegetation, conservation measures, and rainfall characteristics [14]. Among these factors, the most mentioned is rainfall characteristics, as this factor is a prerequisite for runoff and sediment production on hillslopes $[15,16]$. Rainfall is the initial and essential driving force for natural runoff generation and variation in erosion, its potential to breakdown aggregates, the detachment of soil particles, and runoff production [16,17]. Low mountains and hills are intertwined in the red soil region of south China, with mountain area accounting for $33.8 \%$, hill area accounting for $26.7 \%$, hill area accounting for $11.4 \%$, and the three together accounting for more than $70 \%$ [12]. The terrain has large undulations, which provides a huge scouring potential for surface runoff. In this region, the temperature is high, the radiant heat is large, and the weathering effect is strong, forming deep weathering with soft structure and poor erosion resistance, which leads to significant erodibility. Therefore, the soil in the red soil region of southern China is more susceptible to rainfall erosion, which has a greater impact on soil erosion [18]. In addition, vegetation has an important impact on the process of soil erosion $[19,20]$. Many studies have shown that vegetation can increase ground cover, conserve water sources, reduce rain kinetic energy, and block soil erosion [21,22]. Human factors also have a greater impact on soil erosion. Artificially reclaimed land destroys soil stability, and improper human activities, such as deforestation, steep slopes, overgrazing, and inappropriate farming practices, severely weaken soil erosion resistance, causing the rapid development of destructive erosion $[4,23]$. Tillage erosion is one of the more common types of erosion on farmland, of which soil erosion on sloping farmland is more common and serious [24,25]. Twelve percent of the cultivated land (approximately $33,000 \mathrm{~km}^{2}$ ) belongs to the slope cultivated land reclamation along the slope in the red soil hilly area of southern China [12], and slope tillage is the most common and widespread farming method in the area, so these slopes of cultivated land are the main source of sediments in the area. Therefore, to prevent soil erosion and promote agricultural production in areas with serious soil erosion, soil and water conservation tillage measures have gradually attracted the attention of researchers. Countries around the world have applied conservation tillage measures to increase production, and research on conservation tillage has increased [26,27]. Straw mulching is a soil and water conservation tillage 
method for sloping farmland, integrating land use and land reclamation, and it can effectively control water erosion on sloping farmland by increasing coverage [28]. Under different rainfall intensities, straw mulching can retard runoff velocity, increase soil roughness by $0.02-0.03$, reduce flood peak flow and sediment content, and reduce soil erosion by 50-80\% [29]. After no-tillage and stalk mulching, the runoff and soil loss of sloping farmland are reduced by $70 \%$ [30]. In general, the operation of straw mulching is simple, and the effect is remarkable. It is a kind of water, soil, and fertilizer maintenance measure for sloping farmland that should be vigorously promoted. Although the effects of soil and water conservation measures on runoff and erosion have been discussed in previous studies, the relationship between the benefits of different water and soil conservation measures to reduce flow, sediment, and rainfall under natural rainfall conditions needs further study.

In the process of slope erosion, the form of sediment movement and the distance of transport depend not only on the hydrodynamic characteristics of runoff, but also on the nature of the sediment itself, especially the size and density of sediment particles $[15,31]$. Therefore, with the deepening of the research on erosion mechanisms, the classification characteristics of sediment particles in the erosion process are gradually receiving attention [32,33]. It is generally believed that the composition of sediment particles is determined by many factors such as rainfall characteristics, vegetation cover, water flow type (thin layer flow and fine gully flow), soil properties, and slope. Some studies have shown that the amount of clay particles mainly depends on the degree of rainfall damage to aggregates on the soil surface, and the intensity of rain has a greater impact on the distribution of sediment particles than slope [34,35]. Wu et al. (2014) found that the distribution of erosive sediment particles was significantly affected by soil parent material and rainfall erosivity in red soils in subtropical regions [36]. Studies show that most of the soil nutrients are lost with the sediment, and the nitrogen and phosphorus nutrients carried by the sediment can even account for more than $90 \%$ of the total nutrient loss [37,38]. The nutrient distribution of sediment particles of different particle sizes is not uniform; the more particles that are adsorbed, the more nutrients that are adsorbed as well $[39,40]$. Studies have shown that protective farming measures have obvious effects: increasing soil water holding performance, improving soil structure, and improving corrosion resistance and permeability [41,42]. Zhou et al. [43] found that the fine-grained component was the highest in the alfalfa grassland eroded sediment, while the coarse-grained and clay particle content were the lowest, and with the increase in plant density, the enrichment ratio of fine particle components in eroded sediment increased correspondingly, while the enrichment ratio of coarse particle components decreased. In different tillage modes, the particle size gradation continuity of soil loss on the slope is different, and the composition of soil particle loss on the slope is more uniform under a reasonable tillage mode, which can effectively protect the continuity of soil particle gradation on the slope [43]. The influence of vegetation on erosion also affects the particle size separation of the water erosion process [44]. Michaelides et al. [22] found that the contents of fine particles $(<0.063 \mathrm{~mm})$ in grassland erosion sediments were higher than those in other runoff plots (shrubs, bare ground), although their erosion rates were similar. A large number of studies have shown that soil and water conservation measures play an important role in nutrient maintenance and soil erosion prevention and control $[45,46]$. By increasing surface coverage, soil root content, and biodiversity, soil nutrients such as soil organic matter, total nitrogen, total potassium, and total phosphorus are increased. Although there have been many studies on the rules and mechanism of particle size distribution of eroded sand, the effects of soil erosion control and soil and water conservation measures on the composition of eroded sediment particles in red soil regions need to be studied further.

In this study, we investigated surface runoff and soil loss during rainfall events from 2015 to 2018, using five measures (bare land, slope tillage, hedgerows with slope tillage, contour tillage, and straw mulching with conventional tillage) in the red soil region. The purpose of this study was to (1) compare the differences in surface runoff and soil loss under five different measures; (2) analyze the relationship between runoff and sediment reduction efficiency of soil and water conservation measures and rainfall intensity under natural conditions; and (3) compare the differences in sediment particles using different measures. 


\section{Materials and Methods}

\subsection{Study Area}

The study was conducted in the Jiangxi Ecological Science and Technology Park of Soil and Water Conservation (JESTPSWC, $29^{\circ} 16^{\prime} 37^{\prime \prime}-29^{\circ} 17^{\prime} 49^{\prime \prime} \mathrm{N}, 15^{\circ} 42^{\prime} 38^{\prime \prime}-115^{\circ} 43^{\prime} 06^{\prime \prime} \mathrm{E}$ ), which is located in the Yangou small watershed, the west bank of the Boyang River in the Poyang Lake system and is located in Dean County, northern Jiangxi Province (Figure 1). The area is about $80 \mathrm{hm}^{2}$, and this region is dominated by a subtropical monsoon climate with an average annual temperature of $16.7^{\circ} \mathrm{C}$ and the abundant rainfall. The average annual rainfall is $1350.9 \mathrm{~mm}$, the average annual sunshine ranges from 1650 to 2100 h., and the average frost-free period is $249 \mathrm{~d}$. The landform is shallow hilly land with an elevation of 30-100 $\mathrm{m}$ a.s.l. and a slope of 5-25 [47]. The soil parent material is mainly Quaternary red clay, and the zonal vegetation is subtropical evergreen broad-leaved forest. The $\mathrm{pH}$ value of the soil in the test area was 6.67 , the soil organic matter was $8.64 \mathrm{~g} / \mathrm{kg}$, and the composition of the soil particles is shown in Figure 2 [48].
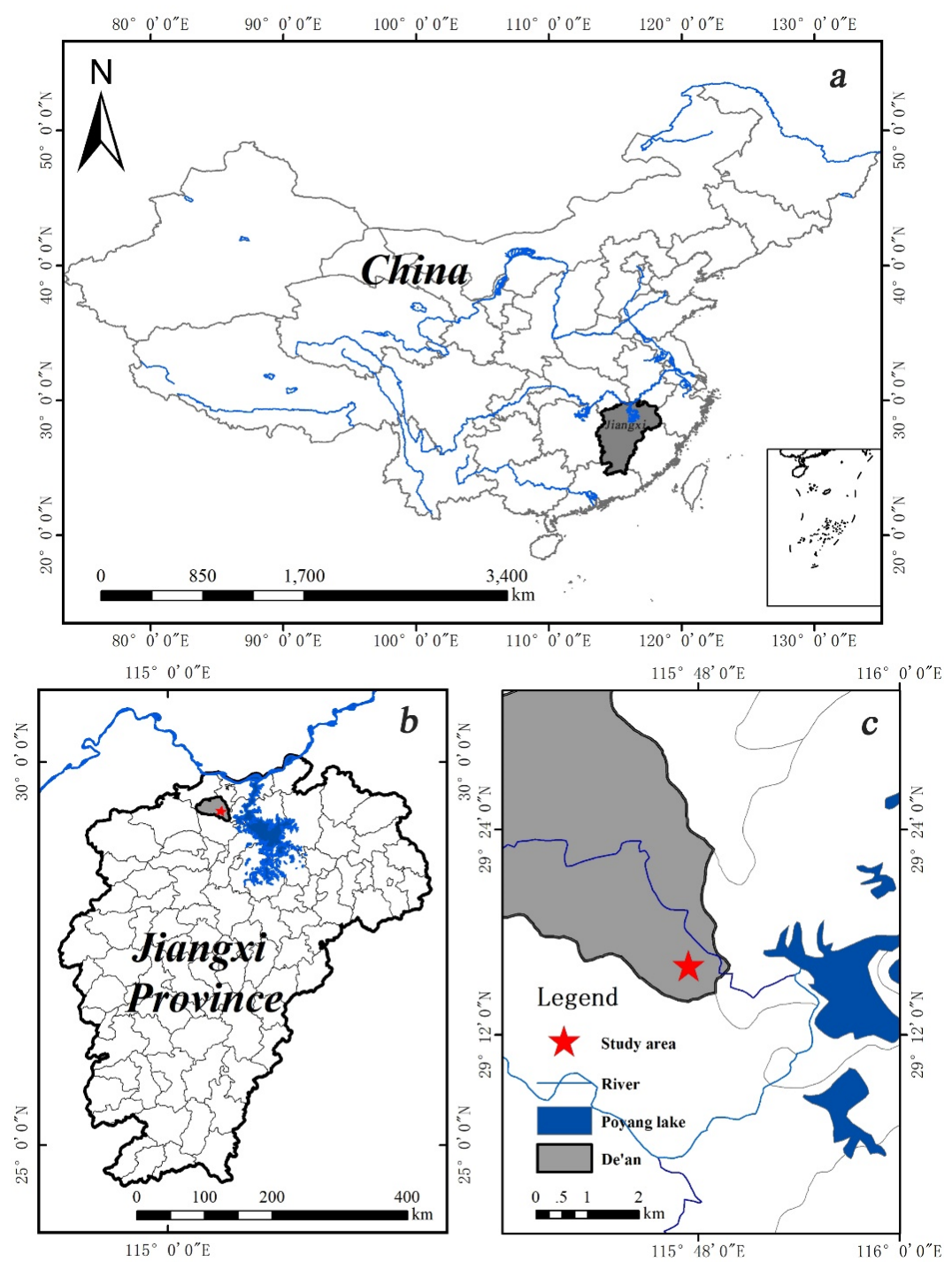

Figure 1. The location of the study area in the center of the red soil region in southern China. The study site was $15 \mathrm{~km}$ west from Poyang Lake, which is the largest freshwater lake in China. Three pictures show the study area: (a) A map of Jiangxi province in China; (b) the study area in Jiangxi province; (c) the position of the study area opposite the river system. 


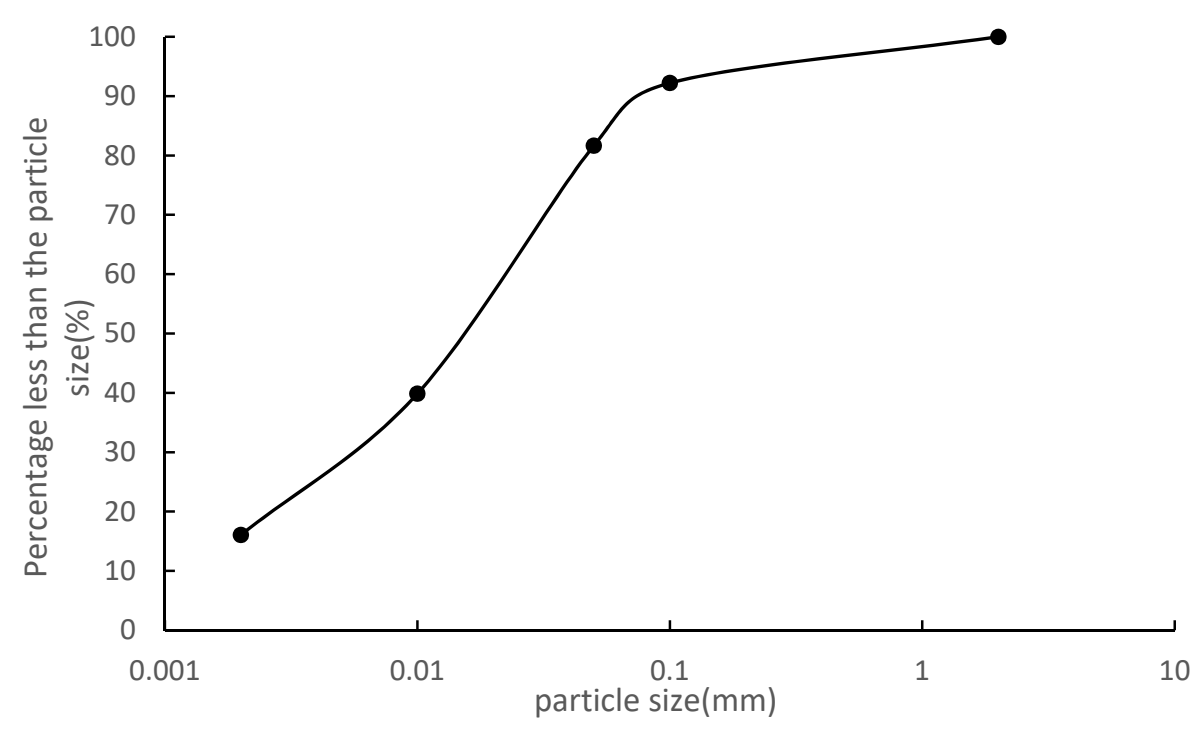

Figure 2. The sieve curve of soil particles.

\subsection{Experimental Design}

The experimental design has five treatments: bare land, slope tillage, hedgerows with slope tillage, contour tillage, and straw mulching with conventional tillage (Figure 3). Bare land, straw mulching with conventional tillage, and contour tillage each have two repetitions, hedgerows with slope tillage and slope tillage each have three repetitions, and each cell is randomly arranged. Bare land: normal soil plowing every year, but no ridges; slope tillage: ridges with a width of $70 \mathrm{~cm}$ and a height of $30 \mathrm{~cm}$ along the slope, and ridges $30 \mathrm{~cm}$ wide and $30 \mathrm{~cm}$ deep. Hedgerows with slope tillage: a ridge with a width of $70 \mathrm{~cm}$ and a height of $30 \mathrm{~cm}$ along the slope, a ridge with a width of $30 \mathrm{~cm}$ and a depth of $30 \mathrm{~cm}$; daylily plant hedges with a width of $0.5 \mathrm{~m}$ are planted at $10 \mathrm{~m}$ and $20 \mathrm{~m}$ distances from the top of the plot, with two rows of plant hedges, a row spacing of $35 \mathrm{~cm}$ and a plant spacing of $20 \mathrm{~cm}$. Contour tillage: a ridge with a width of $70 \mathrm{~cm}$ and a height of $30 \mathrm{~cm}$ along the contour line, and a ditch with a width of $30 \mathrm{~cm}$ and a depth of $30 \mathrm{~cm}$. Straw mulching with conventional tillage: the soil is normally plowed every year, but it does not ridge, and peanuts are evenly covered with dry straw every year after sowing. According to previous research results [49], the application of straw was set at a rate of $10,000 \mathrm{~kg} / \mathrm{hm}^{2}$.

The plot was constructed on a natural slope, each with a size of $20 \mathrm{~m} \times 5 \mathrm{~m}$ (length $\times$ width), with a slope of 10 degrees. The physical and chemical properties of soil are similar between different plots. The plots were adjacent and parallel to the slope, and cement ridges were inserted vertically $30 \mathrm{~cm}$ into the soil and were $20 \mathrm{~cm}$ above the ground at the borders of each plot.

\subsection{Experimental Procedures}

Peanut and rapeseed crops were rotated in the test area. Rape cultivation was planted in early October, and rapeseed was harvested at the end of April. After the rapeseed was harvested, the land was cultivated, and peanuts were planted in accordance with local planting habits. The peanut variety is pure autumn variety 1016 . Peanuts are sown three to a hole. The plant spacing is $15-17 \mathrm{~cm}$, and the row spacing is $30-33 \mathrm{~cm}$. At the time of sowing, base fertilizer, organic calcium magnesium phosphate fertilizer $\left(750 \mathrm{~kg} / \mathrm{hm}^{2}\right)$, and compound fertilizer $\left(375 \mathrm{~kg} / \mathrm{hm}^{2}\right)$ (the N:P: K ratio is 15:15:15) were applied. During the flowering stage, $75 \mathrm{~kg} / \mathrm{hm}^{2}$ urea and $37.5 \mathrm{~kg} / \mathrm{hm}^{2}$ potassium chloride were applied. Bare plots were plowed and fertilized similar to the other plots. After each rainfall event, the sediment in the runoff bucket was stirred evenly, a $500 \mathrm{~mL}$ muddy water sample was collected to determine the sand content, and another $500 \mathrm{~mL}$ muddy water runoff sample was collected to determine the sediment particle composition. 

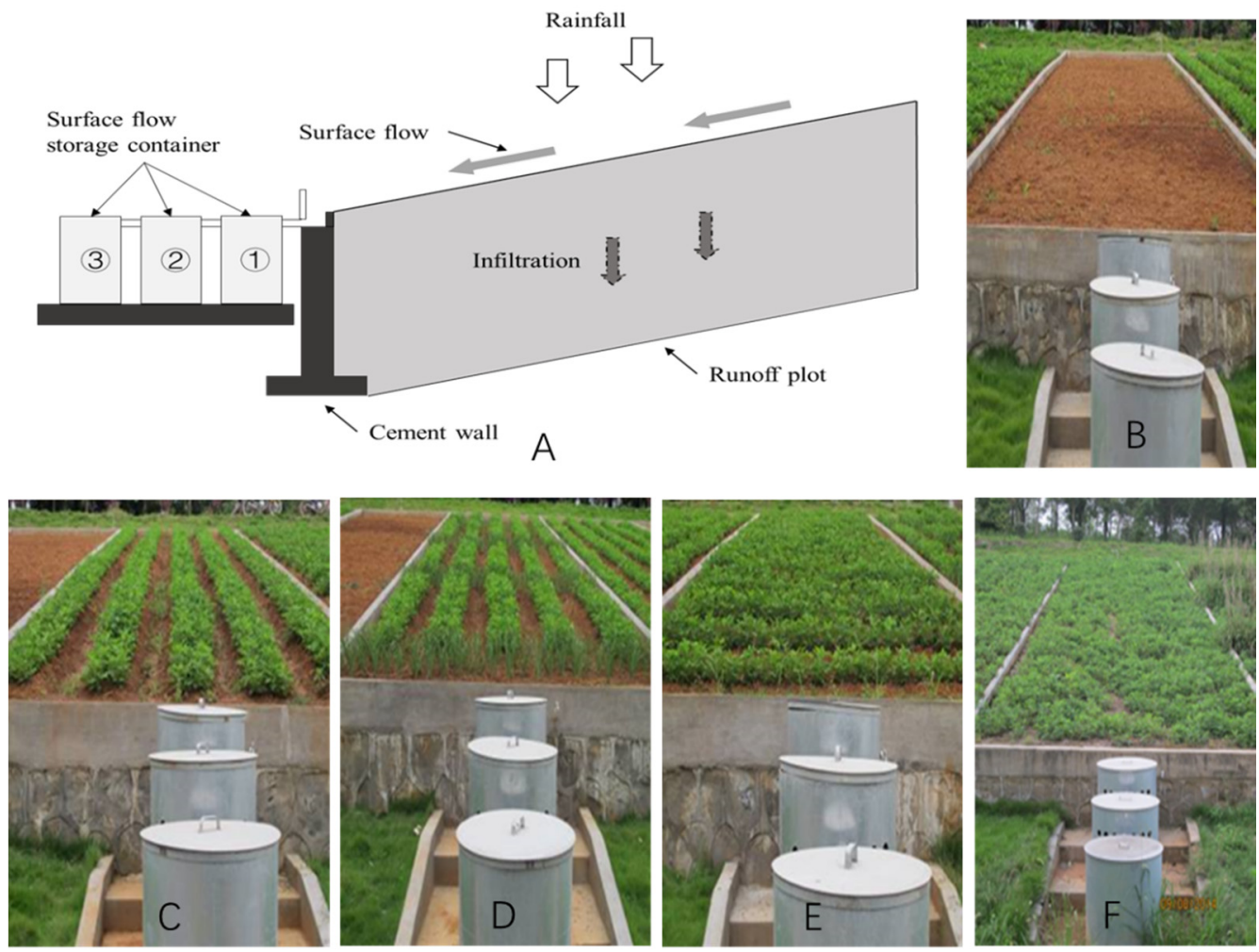

Figure 3. Schematic diagram of the runoff plot (A) and photos of the four runoff plots: bare land (B), slope tillage (C), slope tillage + hedgerows (D), contour tillage (E), and conventional tillage + straw mulching $(\mathbf{F})$.

\subsection{Measurement Items and Methods}

The runoff is calculated according to the scale record of the runoff barrel. The soil loss is calculated by measuring the sandy water sample by the drying method. After passing through a 0.5-mm sieve, the sediment particles were measured by an Eye Tech-Laser particle size analyzer (Ankersmid, Nijmegen, Holland). Granularity tests range from 0.1 micron to 3600 microns. During the data analysis, the sediment particles were divided into three sizes: sticky and powder $(0-0.02 \mathrm{~mm})$, fine sand $(0.02-0.2 \mathrm{~mm})$, and coarse sand $(0.2-0.5 \mathrm{~mm})$. The laser particle size analyzer can measure the average volume diameter. Assuming that the density of each particle size is the same, the mean weight diameter (MWD) is numerically equal to the volume percentage of each particle size multiplied by the sum of the average value of the particle size to obtain the average weight diameter of each sediment particle by the volume weight diameter $[34,50]$. The mean weight diameter (MWD) was calculated using the following formula [51]:

$$
M W D=\sum_{n+1}^{i=1} \frac{r_{i-1}+r_{i}}{2} \times w_{i},
$$

where $r_{i}$ is the ith particle size pore size $(\mathrm{mm}) ; r_{0}=r_{1} ; r_{n}=r_{n+1}$; and $w_{i}$ is the weight percentage of the ith size particle.

The rainfall was measured with a self-recording rain gauge, and characteristic rainfall data such as rainfall duration, rainfall, maximum 5 -min rain intensity $\mathrm{I}_{5}$, maximum 10 -min rainfall intensity $\mathrm{I}_{10}$, maximum 30 -min rainfall intensity $\mathrm{I}_{30}$, and maximum 60 -min rainfall intensity $\mathrm{I}_{60}$ were calculated. The correlation between the rainfall characteristic values and runoff sediment in this paper and soil and water conservation measures for sloping farmland flow and sediment analysis used observation data of rainfall and runoff for 2015 to 2018. The relevant data of the sediment particle composition are the sediment particles eroded by the 2018 rainfall. 


\section{Results}

\subsection{Relationship between Rainfall and Runoff and Sediment Yield on Sloping Farmland}

Based on the analysis of the correlation between the single-field rainfall characteristic values and runoff and sediment data in the four-year (2015-2018) bare-field runoff plot on the slope, the Pearson correlation is shown in Table 1 . It can be seen that the rainfall characteristic indicators are the maximum 5-min rain intensity $\mathrm{I}_{5}$, the maximum 10 -min rain intensity $\mathrm{I}_{10}$, the maximum 30 -min rain intensity $\mathrm{I}_{30}$, and the maximum 60 -min rain intensity $\mathrm{I}_{60}$, which are significantly related to the depth of the secondary rainfall runoff and the soil loss Ms. This indicates that the maximum period rain intensity is the key rainfall characteristic value that affects the sloping farmland runoff and sand production. Among them, the maximum 30-min rain intensity $\mathrm{I}_{30}$ has the largest correlation coefficient with the runoff depth and soil loss. Therefore, the maximum $30-\mathrm{min}$ rain intensity $\mathrm{I}_{30}$ is the best indicator to reflect the single factor of sub-rainfall characteristics.

Table 1. Correlations between rainfall characteristic values and runoff and sediment yield.

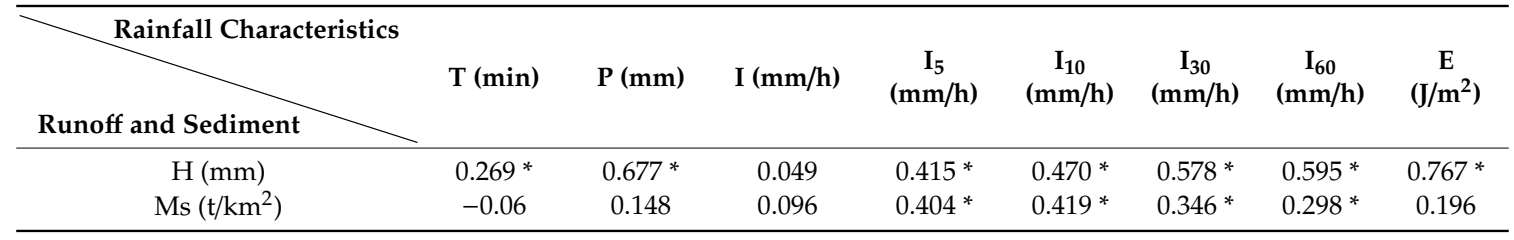

${ }^{*}$ represents the significance level $(p<0.05)$.

Based on the analysis of the fitting relationship between the MWD and $\mathrm{I}_{30}$ of the rainfall and sediment erosion in the bare plots of sloping farmland in 2018, Figure 4 shows that there is a positive linear correlation between the MWD of the rainfall and sediment erosion and $\mathrm{I}_{30}(P<0.01)$. The linear fitting function is that the linear curve $R^{2}$ reaches 0.62 . The above analysis shows that the MWD of eroded sediment increases with the increase in $\mathrm{I}_{30}$, and the rainfall factor $\mathrm{I}_{30}$ is an important factor affecting the MWD of eroded sediment.

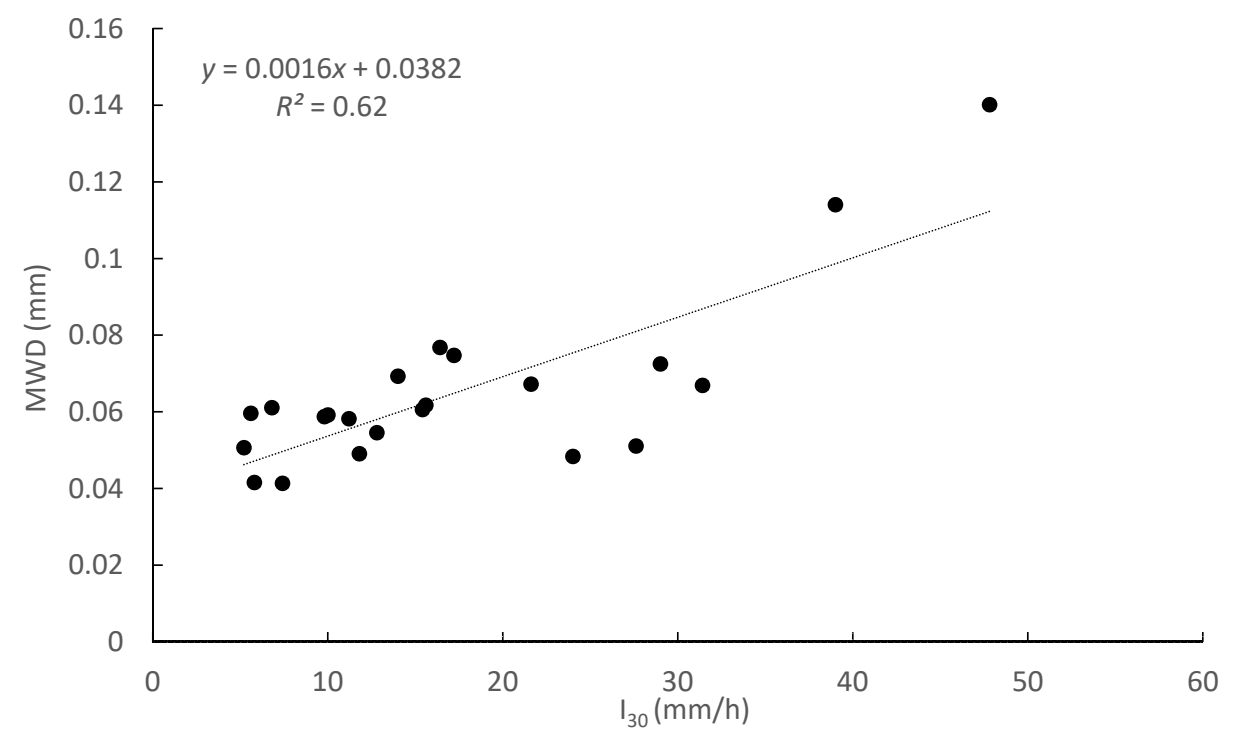

Figure 4. Relationship between $\mathrm{I}_{30}$ rainfall and MWD of eroded sediment.

Figure 5 shows the relationship between the particle composition and $\mathrm{I}_{30}$ during precipitation in the exposed plots of sloping farmland in 2018. It can be seen that with the increase in $\mathrm{I}_{30}$ in the next rainfall, the coarse sand content increases, the fine sand content decreases, and the viscosity and powder content do not change significantly. When $\mathrm{I}_{30}$ is larger than $14 \mathrm{~mm} / \mathrm{h}$, the coarse sand content 
increases with increasing $\mathrm{I}_{30}$, and the fine sand content decreases accordingly. With the increase in the secondary rainfall $\mathrm{I}_{30}$, the kinetic energy and runoff of the rainfall increase, and the kinetic energy of runoff on the slope increases, so the coarse sand content increases. When rainfall $\mathrm{I}_{30}$ is small, the runoff carrying capacity is small, and the gradation distribution of the sediment particles does not change significantly. When $\mathrm{I}_{30}$ reaches $14 \mathrm{~mm} / \mathrm{h}$ and the rainfall kinetic energy is large enough, the runoff carrying capacity increases significantly and the content of coarse sand that is transported continues to increase, resulting in an increase in the amount of coarse sand.

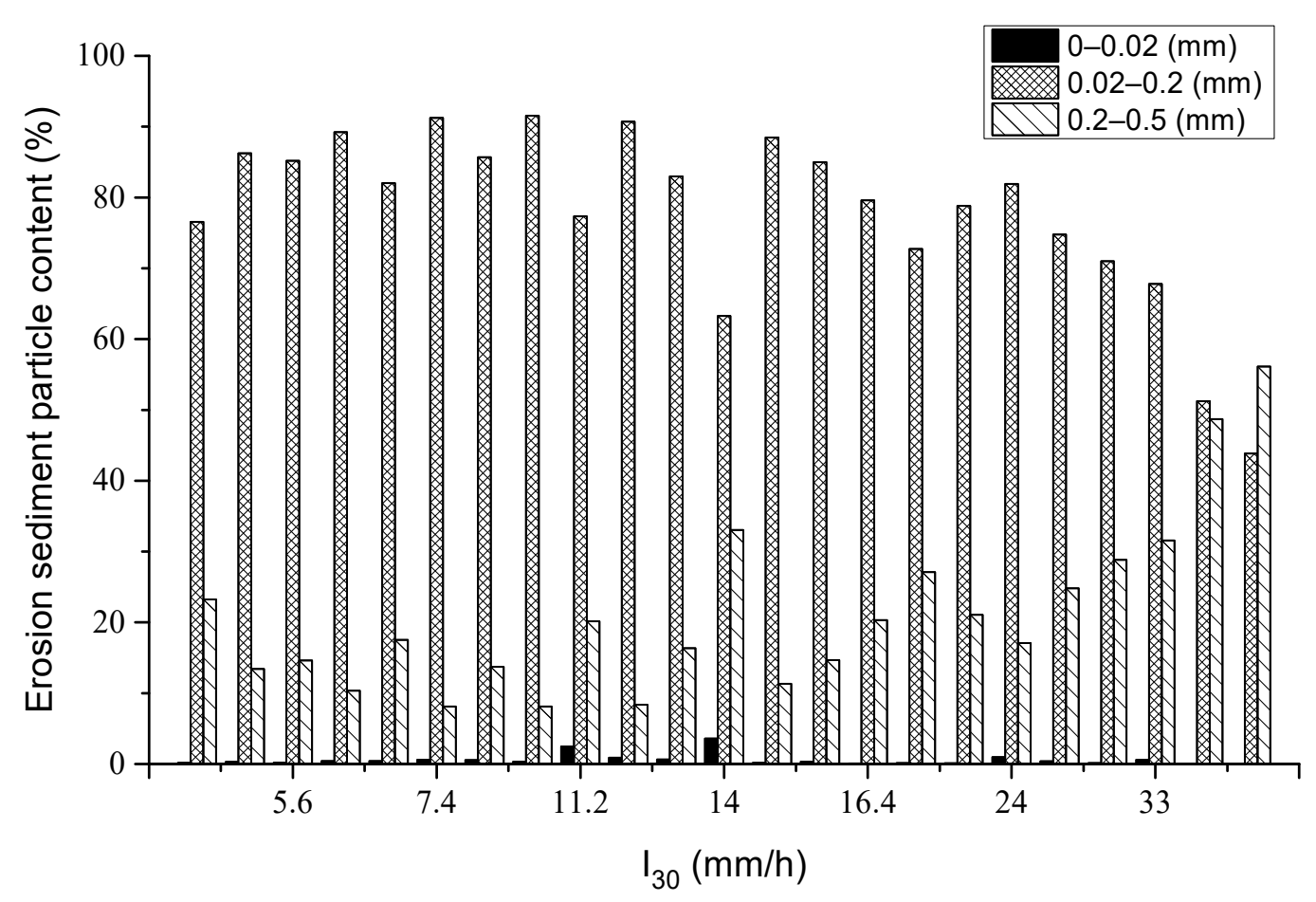

Figure 5. Gradation distribution of sediment particles under different rainfall intensities.

The above analysis shows that the rainfall $\mathrm{I}_{30}$ affects the important rainfall characteristic factors of the gradation of the total runoff and sediment yields and eroded sediments on the red soil slope farmland during the next rainfall. Therefore, it is necessary to combine them with $\mathrm{I}_{30}$ to evaluate the benefits of soil and water conservation measures under one rainfall.

\subsection{Impact of Soil and Water Conservation Measures on Sloping Farmland Flow}

An analysis of the annual average runoff depth under the five treatments of sloping farmland, slope tillage, hedgerows with slope tillage, contour tillage, and straw mulching with conventional tillage from 2015 to 2018 is shown in Figure 6. It can be seen that the runoff depth, in descending order, is from bare to large, slope tillage, hedgerows with slope tillage, straw mulching with conventional tillage, and contour tillage. According to the $t$-test, the runoff depth of the bare land is significantly greater than that of the other treatments. The slope tillage is $32.56 \%$, and the runoff depth of the slope tillage is significantly greater than that of hedgerows with slope tillage, contour tillage, and straw mulching with conventional tillage. The flow-reducing effects of hedgerows with slope tillage, straw mulching with conventional tillage, and contour tillage relative to slope tillage were $49.38 \%, 76.27 \%$, and $81.17 \%$, respectively. The above analysis shows that increasing the ground cover after planting crops on sloping land can significantly reduce surface runoff, and further adopting soil and water conservation measures can significantly reduce surface runoff. 


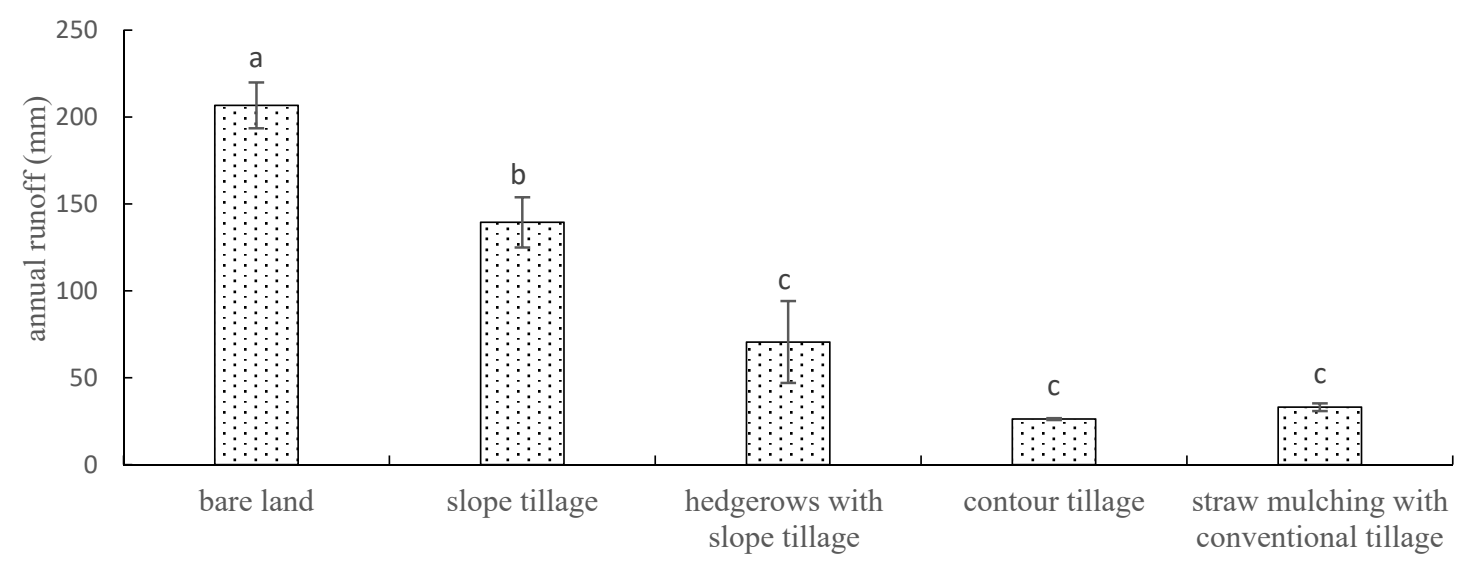

Figure 6. Annual average runoff depth under different treatments.

Figure 7 shows the relationship between $\mathrm{I}_{30}$ and the reduction effect of soil and water conservation measures on sloping farmland under four-year rainfall conditions from 2015 to 2018 . It can be seen that the flow-reduction effect of the different measures together increases with $\mathrm{I}_{30}$, and the fluctuation range decreases with $\mathrm{I}_{30}$. When $\mathrm{I}_{30}$ is less than or equal to $20 \mathrm{~mm} / \mathrm{h}$, the flow-reduction effect of soil and water conservation measures has a negative value, ranging from $-45 \%$ to $100 \%$. The coefficients of variation of hedgerows with slope tillage, contour tillage, and straw mulching with conventional tillage are $77.6 \%, 117.4 \%$, and $69.3 \%$, respectively. When $\mathrm{I}_{30}$ is greater than $20 \mathrm{~mm} / \mathrm{h}$, the flow-reduction effects of soil and water conservation measures are all positive. When $\mathrm{I}_{30}$ is $20-40 \mathrm{~mm} / \mathrm{h}$, the flow-reduction effect of soil and water conservation measures is $2.1-94.9 \%$, and the coefficients of variation of hedgerows with slope tillage, contour tillage, and straw mulching with conventional tillage are $34.5 \%, 47.8 \%$, and $28.6 \%$, respectively. When $\mathrm{I}_{30}$ is greater than $40 \mathrm{~mm} / \mathrm{h}$, the flow-reduction effect of soil and water conservation measures is 39.5-95.7\%, and the coefficients of variation of hedgerows with slope tillage, contour tillage, and straw mulching with conventional tillage are $24.3 \%, 11.4 \%$, and $19.0 \%$, respectively.

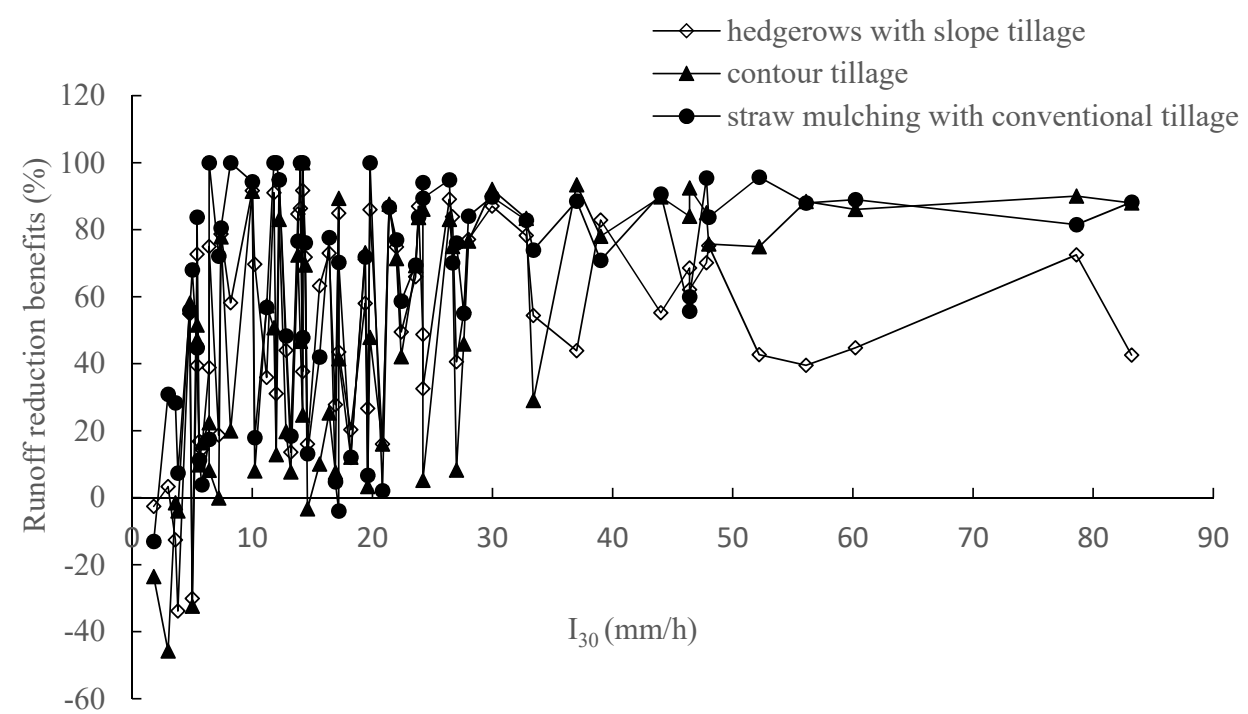

Figure 7. Relationship between the flow-reduction effect of different measures and $\mathrm{I}_{30}$.

Comparing hedgerows with slope tillage, contour tillage, straw mulching with conventional tillage and slope tillage in the four-year sloping farmland from 2015 to 2018, we analyzed the flow-reduction effects of different soil and water conservation measures under different $\mathrm{I}_{30}$ ranges, as shown in Table 2 . It can be seen that the flow-reduction effect of the plant hedge first increases and then decreases with the increase in $\mathrm{I}_{30}$. The flow-reduction effect of contour tillage and straw mulching with conventional 
tillage increases with the increase in $\mathrm{I}_{30}$. The standard deviation of the flow-reduction effect of different measures decreases with increasing $\mathrm{I}_{30}$. When $\mathrm{I}_{30}$ is less than or equal to $20 \mathrm{~mm} / \mathrm{h}$, the flow-reduction effect of soil and water conservation measures is small, and the standard deviation is large. When $\mathrm{I}_{30}$ is greater than $20 \mathrm{~mm} / \mathrm{h}$, the flow-reduction effect becomes large, and the standard deviation decreases. The above analysis shows that different water and soil conservation measures have different $\mathrm{I}_{30}$ ranges, and the flow-reduction effects vary significantly. Contour plant hedges mainly use hedges and plants to intercept runoff, and the gap between hedges is large. The effect is obvious when $\mathrm{I}_{30}$ is in a small range. After $\mathrm{I}_{30}$ is greater than $40 \mathrm{~mm} / \mathrm{h}$, the kinetic energy of the rainfall is large, the runoff is large, and its reducing effect is gradually weakened. The contour tillage has a constant height ridge every $0.3 \mathrm{~m}$, the ridge is dense, and the flow-reduction effect increases with the increase in $\mathrm{I}_{30}$.

Table 2. Flow-reduction effects of different measures and different $\mathrm{I}_{30}$ cultivated land.

\begin{tabular}{ccccccc}
\hline & \multicolumn{3}{c}{ Flow-Reduction Effect (\%) } & \multicolumn{3}{c}{ Standard Deviation } \\
\cline { 2 - 7 } $\mathbf{I}_{\mathbf{3 0}}(\mathbf{m m} / \mathbf{h})$ & $\begin{array}{c}\text { Hedgerows with } \\
\text { Slope Tillage }\end{array}$ & $\begin{array}{c}\text { Contour } \\
\text { Tillage }\end{array}$ & $\begin{array}{c}\text { Straw Mulching } \\
\text { with Conventional } \\
\text { Tillage }\end{array}$ & $\begin{array}{c}\text { Hedgerows } \\
\text { with Slope } \\
\text { Tillage }\end{array}$ & $\begin{array}{c}\text { Contour } \\
\text { Tillage }\end{array}$ & $\begin{array}{c}\text { Straw Mulching } \\
\text { with Conventional } \\
\text { Tillage }\end{array}$ \\
\hline $0-20$ & 45.6 & 30.4 & 53.1 & 35.4 & 35.7 & 36.8 \\
$20-40$ & 64.1 & 62.5 & 74.8 & 22.1 & 29.9 & 9.5 \\
$>40$ & 56.4 & 83.1 & 80.4 & 13.7 & 15.3 & \\
\hline
\end{tabular}

\subsection{Impact of Soil and Water Conservation Measures on Sloping Farmland Erosion and Sediment Yield}

The analysis of the average annual soil erosion moduli under the five treatments of sloping farmland, slope tillage, hedgerows with slope tillage, contour tillage, and straw mulching with conventional tillage from 2015 to 2018 is shown in Figure 8. It can be seen that the soil erosion moduli, in order from large to small, are bare land, slope tillage, hedgerows with slope tillage, contour tillage, and straw mulching with conventional tillage. The $t$-test showed that the annual erosion modulus of the bare land was significantly larger than that of the other treatments, and that of the slope tillage was $59.33 \%$ relative to the bare land. The $t$-test results showed that the soil erosion modulus of slope tillage was significantly greater than that of hedgerows with slope tillage, contour tillage, and straw mulching with conventional tillage. The sand-reduction effects of hedgerows with slope tillage, contour tillage, and straw mulching with conventional tillage relative to that of slope tillage are $78.58 \%, 93.05 \%$, and $96.20 \%$, respectively. The $t$-test showed that the annual soil erosion modulus of hedgerows with slope tillage was significantly greater than that of hedgerows with contour tillage and straw mulching with conventional tillage, and there was no significant difference in contour tillage or straw mulching with conventional tillage. The above analysis shows that increasing the surface coverage after planting crops on sloping farmland can significantly reduce the soil erosion modulus, and the soil erosion modulus can be significantly reduced by using soil and water conservation measures during the cultivation of sloping farmland. Contour tillage and straw mulching with conventional tillage are more effective than other measures.

The relationship between the sand-reduction effects of soil and water conservation measures on sloping farmland and $\mathrm{I}_{30}$ under rainfall conditions for four years from 2015 to 2018 is shown in Figure 9. With the increase in $\mathrm{I}_{30}$, the sand-reduction effects of different soil and water conservation measures have an overall increasing trend, and the coefficients of variation of the sand-reduction effects have a decreasing trend. When $\mathrm{I}_{30}$ is less than or equal to $20 \mathrm{~mm} / \mathrm{h}$, the sediment-reduction effects of the soil and water conservation measures have negative values, and the range of the sand-reduction effect is $-94.4-100 \%$. The coefficients of variation of hedgerows with slope tillage, contour tillage, and straw mulching with conventional tillage are $61.8 \%, 169.5 \%$, and $40.2 \%$, respectively. When $\mathrm{I}_{30}$ is greater than $20 \mathrm{~mm} / \mathrm{h}$, the sediment-reduction effects of soil and water conservation measures are all positive. When $\mathrm{I}_{30}$ is $20-40 \mathrm{~mm} / \mathrm{h}$, the effect of soil and water conservation measures on sand reduction is between $-14.3 \%$ and $24.66 \%$. The coefficients of variation of the hedge-reduction effects of hedgerows with slope tillage, contour tillage, and straw mulching with conventional tillage are $42.4 \%, 44.3 \%$, 
and $33.1 \%$, respectively. When $\mathrm{I}_{30}$ is greater than $40 \mathrm{~mm} / \mathrm{h}$, the soil and water conservation measures have a sand-reduction effect between $35.8 \%$ and $99.8 \%$. The coefficients of variation of hedgerows with slope tillage, contour tillage, and straw mulching with conventional tillage are $19.2 \%, 15.9 \%$, and $24.5 \%$, respectively.

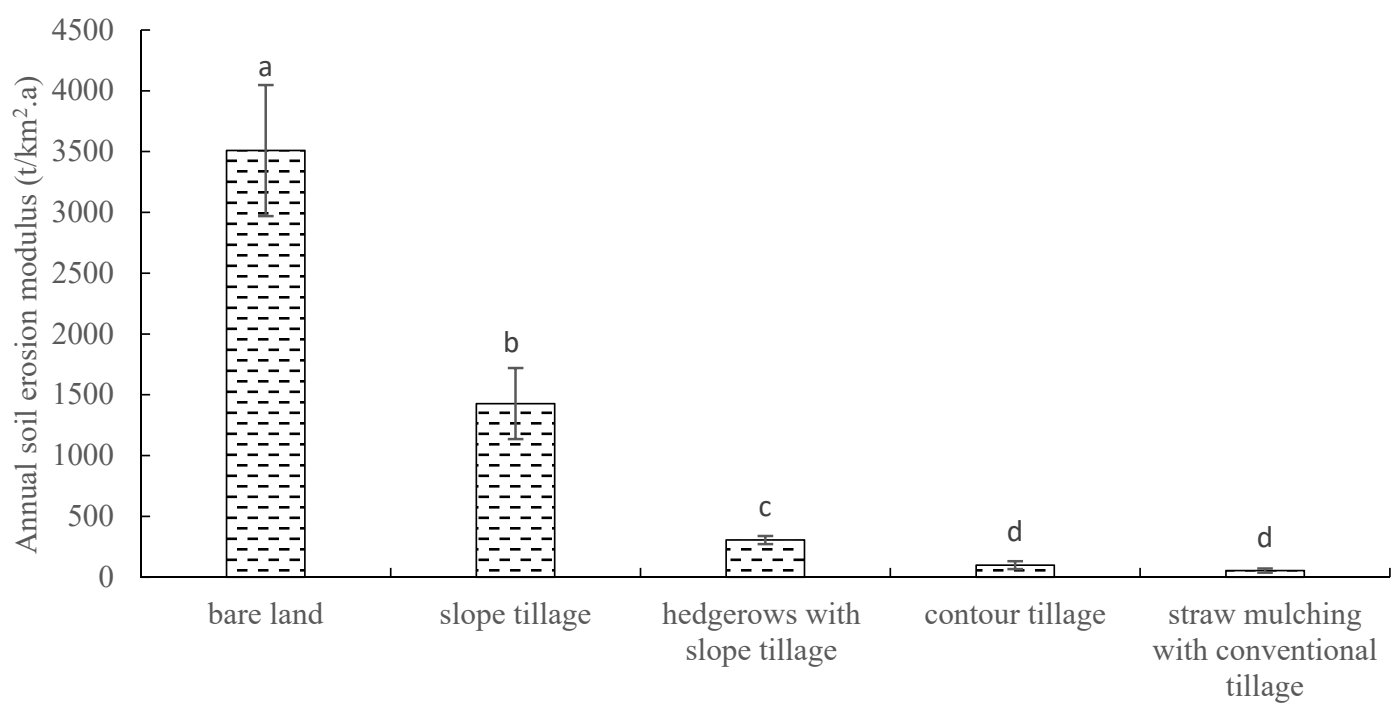

Figure 8. Average annual soil erosion moduli under different treatments.

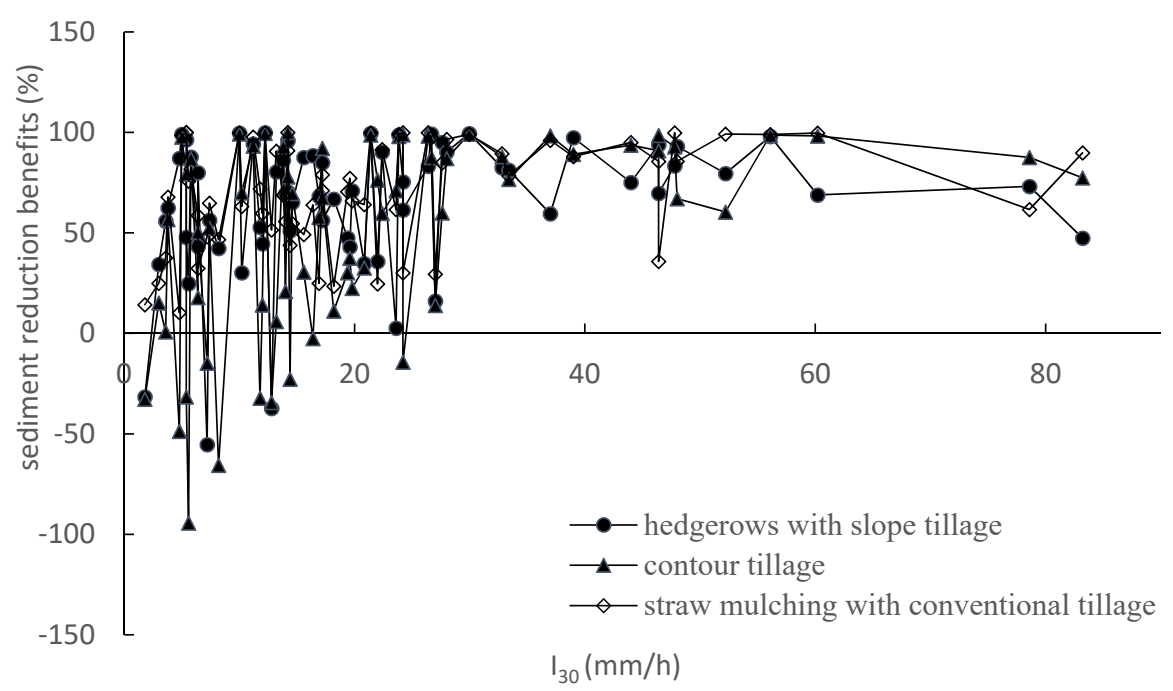

Figure 9. Relationship between the effects of different measures on sediment reduction and $\mathrm{I}_{30}$.

We conducted a comparative analysis of different soil and water conservation measures under different $\mathrm{I}_{30}$ ranges on the effects of sand reduction on hedgerows with slope tillage, contour tillage, straw mulching with conventional tillage, and slope tillage in 2015-2018. Table 3 shows that the flow-reduction effects of hedgerows with slope tillage, contour tillage, and straw mulching with conventional tillage all increase with increasing $\mathrm{I}_{30}$, and the standard deviation decreases with increasing $\mathrm{I}_{30}$. The ranking of the overall effect of sediment reduction by different measures is straw mulching with conventional tillage, contour tillage, and hedgerows with slope tillage. When $\mathrm{I}_{30}$ is $0-20 \mathrm{~mm} / \mathrm{h}$, contour tillage is the smallest, which indicates that contour tillage is not as good as hedgerows with slope tillage under the conditions of less $\mathrm{I}_{30}$ rainfall, and straw reduction measures have higher effects under different rainfall conditions. 
Table 3. Sand-reduction effects of different measures and different $\mathrm{I}_{30}$ arable land.

\begin{tabular}{ccccccc}
\hline & \multicolumn{3}{c}{ Flow-Reduction Effect (\%) } & \multicolumn{3}{c}{ Standard Deviation } \\
\cline { 2 - 7 } $\mathbf{I}_{\mathbf{3 0}}(\mathbf{m m} / \mathbf{h})$ & $\begin{array}{c}\text { Hedgerows with } \\
\text { Slope Tillage }\end{array}$ & $\begin{array}{c}\text { Contour } \\
\text { Tillage }\end{array}$ & $\begin{array}{c}\text { Straw Mulching } \\
\text { with Conventional } \\
\text { Tillage }\end{array}$ & $\begin{array}{c}\text { Hedgerows } \\
\text { with Slope } \\
\text { Tillage }\end{array}$ & $\begin{array}{c}\text { Contour } \\
\text { Tillage }\end{array}$ & $\begin{array}{c}\text { Straw Mulching } \\
\text { with Conventional } \\
\text { Tillage }\end{array}$ \\
\hline $0-20$ & 59.2 & 30.8 & 64.1 & 36.6 & 52.2 & 25.8 \\
$20-40$ & 72.39 & 73.29 & 79.46 & 30.72 & 32.48 & 26.28 \\
$>40$ & 78.25 & 86.54 & 85.12 & 15 & 13.72 & 20.88 \\
\hline
\end{tabular}

\subsection{Effects of Soil and Water Conservation Measures on the Particle Size of Eroded Mud on Sloping Farmland}

The average analysis of the MWD of the five types of sloping farmland for the next rainfall erosion is shown in Figure 10. The MWD of erosion and sediment under different treatments are in the order of bare land, slope tillage, hedgerows with slope tillage, contour tillage, and straw mulching with conventional tillage. According to the $t$-test, the MWD of slope sediment erosion is significantly smaller than that of bare land. The MWD of hedgerows with slope tillage and contour tillage are significantly smaller than that of slope tillage, and the MWD of straw mulching with conventional tillage is significantly smaller than that of slope tillage and hedgerows with slope tillage. The above analysis shows that, after planting crops on sloping farmland, the erosion and sediment MWD can be significantly reduced. After soil and water conservation measures are adopted on sloping farmland, the MWD in eroded sediment can be reduced. Straw mulching with conventional tillage has the best effect on reducing the MWD of eroded sediment particles and can achieve significant effects.

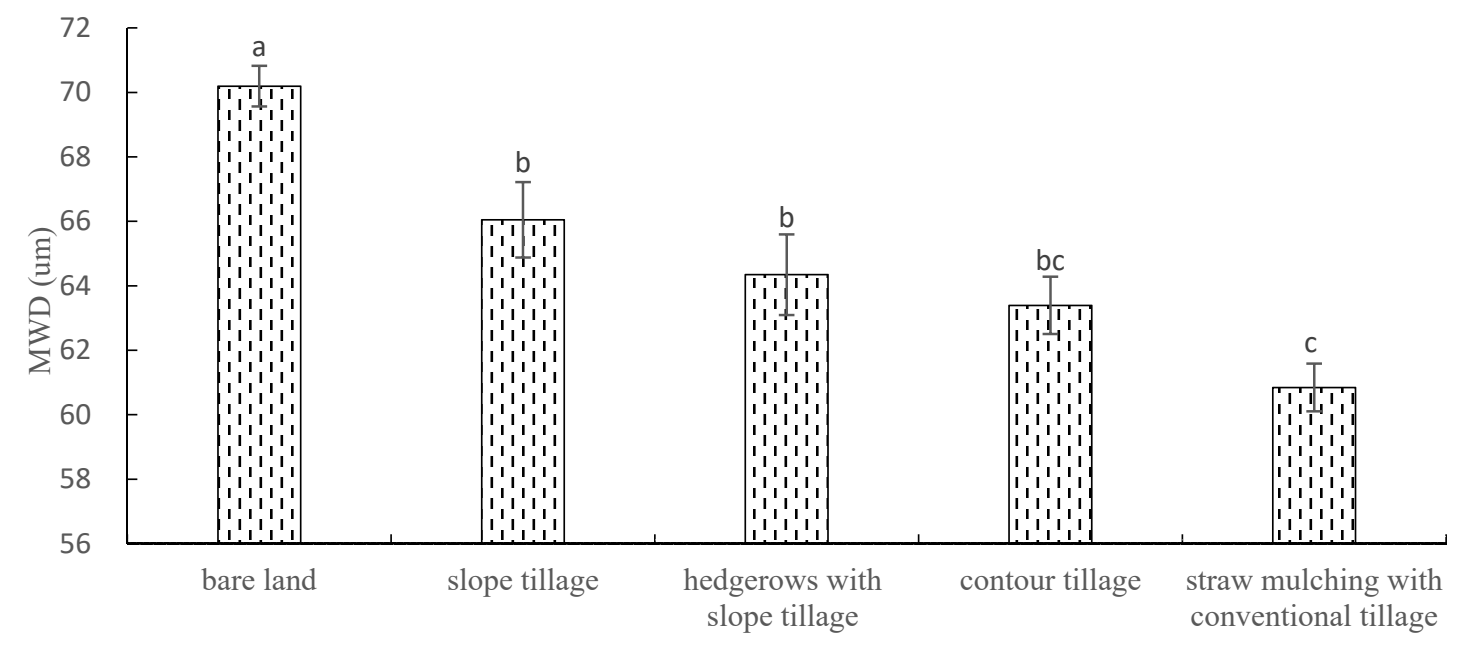

Figure 10. Mean MWD of erosion and sediment erosion under different treatments.

The grading analysis of the different particle size distributions of erosion sediment from the five types of sloping farmland during the next rainfall is shown in Figure 11. It can be seen that the content of coarse sand $(0.2-0.5 \mathrm{~mm})$ in the eroded sediment of sloping farmland is the largest in the order of bare land followed by slope tillage, the difference between hedgerows with slope tillage and contour tillage is not the same, and straw mulching with conventional tillage is the lowest. Compared with bare land, the increase in coarse sand content along slope tillage, hedgerows with slope tillage, contour tillage, and straw mulching with conventional tillage was $12.11 \%, 19.04 \%, 18.49 \%$, and $31.12 \%$, respectively. The content of fine sand $(0.02-0.2 \mathrm{~mm})$ in the eroded sediment is the largest in straw mulching with conventional tillage, the second-highest represents the difference between contour tillage and hedgerows with slope tillage, the third-highest is in slope tillage, and the lowest is in bare land. Compared with bare land, the increase in fine sand content in slope tillage, hedgerows with slope tillage, contour tillage, and straw mulching with conventional tillage was $4.02 \%, 6.34 \%, 6.40 \%$, and $10.36 \%$, respectively. There was no significant difference in the thickness and particle size of the 
erosion and sediment $(0-0.02 \mathrm{~mm})$ between different treatments, but the content of fine sand with straw mulching with conventional tillage content was still the largest. The above analysis shows that, after planting crops on sloping land, the ground coverage is increased and the kinetic energy and runoff energy of rainfall are reduced, which reduces the runoff and sand transport capacity, resulting in a reduction in the coarse sand content. After taking soil and water conservation measures on sloping farmland, the soil and water conservation measures will further intercept runoff energy and further reduce the transport of coarse sand. Among soil and water conservation measures, straw mulching with conventional tillage is best at intercepting coarse particles.

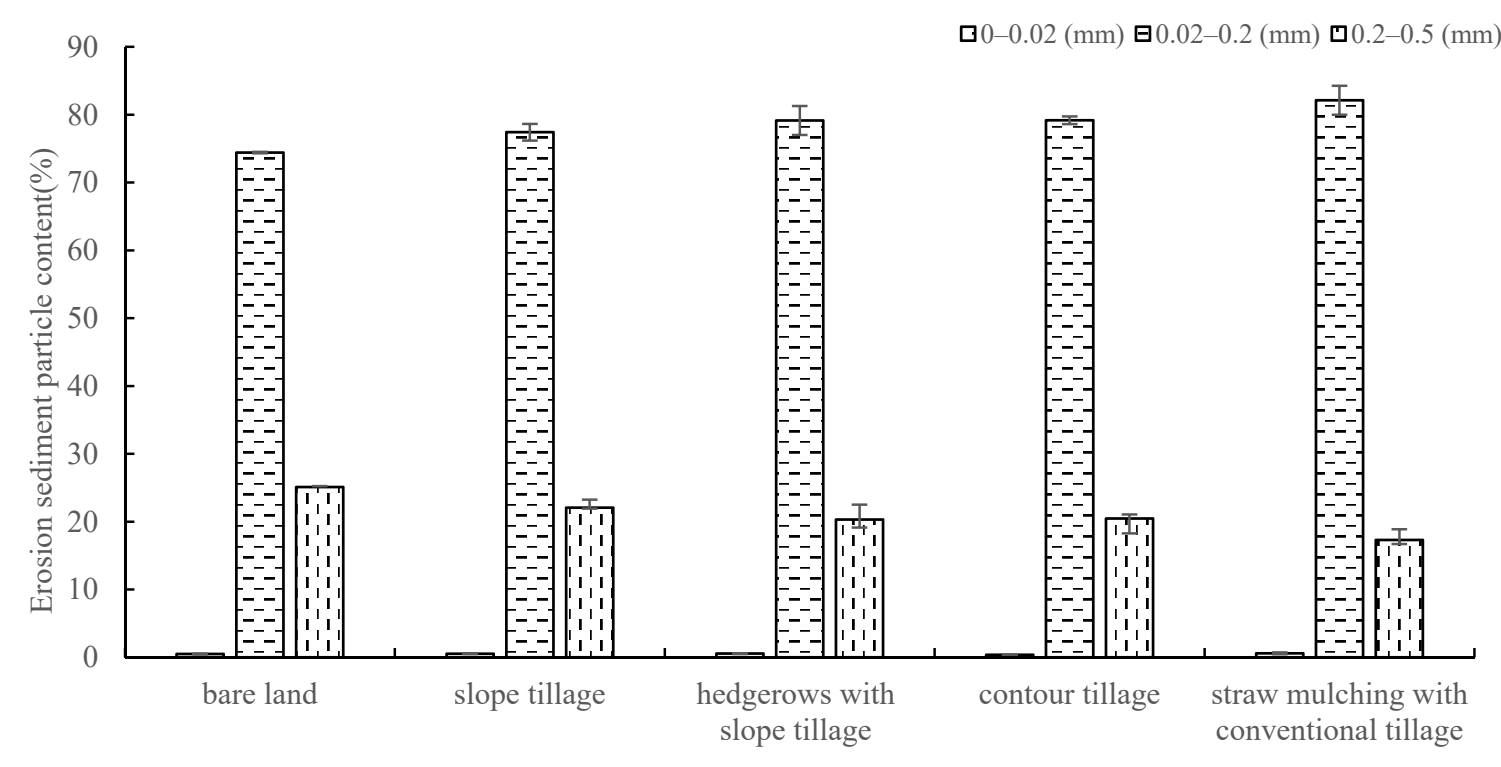

Figure 11. Grain size distribution of sediment erosion under different treatments.

\section{Discussion}

Rainfall is the driving force behind slope erosion, and rainfall intensity, secondary rainfall, rainfall duration, and rainfall kinetic energy are closely related to slope erosion characteristics [52]. As rainfall intensity increases, both rainfall erosivity and runoff erosivity increase [53]. In this study, the erosion intensity of sloping farmland and its MWD increased with increasing rainfall intensity (Table 2; Figure 4). Under rainfall conditions, the external forces of raindrop splashing and runoff scouring and the disintegration of aggregates cause different degrees of fragmentation, resulting in different distributions of eroded sediment particles [54]. An increase in the kinetic energy of raindrops will enhance the transport capacity of runoff. Eroded sediment particles contain relatively coarse soil particles, while the corresponding clay content is reduced [55]. There is a positive correlation between the numerical value of the sediment particle size on the bare ground and rainfall kinetic energy and runoff coefficient. With the increase in rainfall $\mathrm{I}_{30}$, rainfall kinetic energy, rainfall erosivity, and runoff erosivity increase, the fine sand content decreases, and the coarse sand content increases (Figure 5). The increase in coarse particles and the decrease in fine particles in the eroded sediment will inevitably lead to an increase in the MWD value of the sediment.

Runoff and sediment production on the slope are closely related to land use types, vegetation coverage, and soil and water conservation measures. These results indicate that rainfall's effect on soil erosion is influenced by land use [56]. Soil and water conservation measures or conservation tillage systems can reduce runoff and sediment yield on slopes by increasing the ground cover, underlying surface roughness, and infiltration, slowing runoff rates, and consuming runoff energy. Thus, traditional, intensive inversion tillage (TT) is being replaced by conservation tillage systems. To be considered conservation tillage (CT), any tillage and planting system must maintain at least $30 \%$ of the soil surface covered by residue after planting to reduce soil erosion by water [57]. Types of CT include 
no-tillage (NT), reduce tillage (RT), ridge tillage, mulch tillage, and zone tillage. Some reductions in total runoff and erosion due to RT management have been reported previously for different types of crop $[58,59]$. However, soil and water conservation measures such as ridge tillage and mulch tillage are more common in the red soil area of southern China. Compared with slope tillage without soil and water conservation measures, hedgerows with slope tillage, contour tillage, and straw mulching with conventional tillage have significant benefits in terms of reducing flow and sediment (Figures 6 and 8); this result is similar to Zhou's from 2019 [60]. The intensity of the secondary rainfall affects the amount of runoff and sediment produced on the slope and the sediment particle grading. Therefore, the benefits of soil and water conservation measures for reducing rainfall and reducing sediment flow must be related to rainfall intensity. When the rainfall reaches a certain level, the runoff and sediment yield of the control slope without soil and water conservation measures are significantly larger than those with soil and water conservation measures. When the rainfall is relatively heavy, soil and water conservation measures play a significant role in reducing water and sediment on the slope [57]. Song et al.'s [61] research on soil erosion of black soil slopes in China found that, with the increase in rain intensity, the runoff and sediment volume of various farming measures showed an increasing trend, and different farming measures have a certain effect on the soil volume of rainwater under different rain intensity conditions, but the degree of impact under different rain intensity conditions is different. This study found (Figure 7, Table 2; Figure 9, Table 3) that when the rainfall $\mathrm{I}_{30}$ is less than $20 \mathrm{~mm} / \mathrm{h}$, the coefficient of variation is large, and the main rainfall is small, the runoff on the slope is small; there is local runoff on the slope, the soil and water conservation measures are incomplete, and occasionally the factors are large. Therefore, the benefits of soil and water conservation measures for reducing flow and sediment are not only small, but also the coefficient of variation is large. With the increase in $\mathrm{I}_{30}$, the slope has a full-scale runoff and soil and water conservation measures have taken full effect, meaning the benefits of soil and water conservation measures to reduce flow and sediment increase, and the coefficient of variation decreases.

In this study, it was found that, after the crops were planted on the slope, the coarse sand content decreased and the fine sand content increased. After taking soil and water conservation measures, the coarse sand content was further reduced, and the fine sand content was increased (Figure 11). There is a positive correlation between the MWD and coarse particle content in eroded sediment. Qiu et al. [43] found that vegetation and straw mulching can effectively reduce the impact of raindrops on the ground surface and reduce the amount of slope erosion. The number of coarse particles in the eroded sediment becomes smaller, the number of fine particles increases, and the average particle diameter becomes smaller. Therefore, planting plants on slopes can significantly reduce the MWD in eroded sediment, and different soil and water conservation measures can further reduce the MWD in eroded sediment (Figure 10). A contour tillage ditch on a slope can slow down the surface runoff, and runoff can even be stored in the ditch even under light rain, so that coarse particles are deposited in the ditch [62,63]. In contrast, straw mulch can more effectively intercept coarse particles [61]; this outcome is similar to the results of this study. The reduction in coarse particles can reduce the MWD in the sediment. Straw mulching with conventional tillage reduces the MWD in the eroded sediment by $8 \%$, achieving a significant effect (Figure 10). Under natural rainfall conditions, vegetation can intercept sediment and change the sediment particle gradation [64]. Therefore, after planting crops on the slope, relatively bare land has increased surface coverage and reduced slope erosion and its coarse sand content. Farming activities such as the plowing of sloping land disturb the ground every year. At the same time, due to the growth period of crops, seasonal differences in vegetation coverage are large, and the intensity of soil erosion is large. The study found that slope yield and sediment yield in the purple soil area of China decreased with the increase in vegetation coverage, and vegetation coverage of $50 \%$ can play a role in soil and water conservation [65]. Therefore, it is necessary to take soil and water conservation measures to reduce soil erosion on slope farmland, conserve soil, and maintain the sustainability of soil fertility. However, except for soil vegetation cover, the soil tillage erosion can be controlled by reducing operations, regulating speed and depth, and choosing 
more sustainable tillage tools [66]. Contour tillage can effectively reduce slope erosion, but when rainfall is heavy, severe ridge erosion may occur due to broken ridges [67]. Wang et al. [68] believe that, although horizontal ridge cultivation destroys the stability of the soil structure when plowing the soil, because the root system of densely planted plants fixes the soil and absorbs a large amount of water in the soil to slow down the downward momentum of runoff, the yield is small. Straw mulch and hedgerows can block some rainfall energy [69] and reduce soil erosion [70,71], but when the heavy rain is strong, the interception of runoff and sediment by plant hedges is significantly reduced. After red soil sloping farmland is planted, even at the seedling stage, the crop coverage is almost $0 \%$. At this time, it is just into the flood season. Frequent, heavy rainfall can lead to severe soil erosion. Planting hedges and cross-slope cultivation at this time of heavy rainfall were hampered by erosion and sediment production. Straw mulch measures are generally already covered at the seedling stage of crops, and their coverage is close to $100 \%$. Therefore, the benefits of reducing flow and sediment are the best; the interception of coarse particles is an especially good soil and water conservation measure for slope farmland.

\section{Conclusions}

Surface runoff and soil loss data from 66 storms for runoff plots with five typical measures, including bare land, slope tillage, hedgerows with slope tillage, contour tillage, and straw mulching with conventional tillage, were analyzed in this study. The runoff and soil erosion increase significantly with increasing $\mathrm{I}_{30}$. The particle size of eroded sediment on sloping farmland is related to $\mathrm{I}_{30}$. With the increase in $\mathrm{I}_{30}$, the MWD of eroded sediment increases, the coarse sand content increases, and the fine sand content decreases.

The surface runoff differed significantly between the different measures. Surface runoff can be significantly reduced by hedgerows with slope tillage, straw mulching with conventional tillage, and contour tillage on sloping farmland. The flow-reduction effects of contour tillage and straw mulching with conventional tillage both increase with the increase in $\mathrm{I}_{30}$, while those of hedgerows with slope tillage first increase and then decrease. The coefficient of variation and standard deviation of the flow-reduction effect of different soil and water conservation measures all decrease with the increase in $\mathrm{I}_{30}$.

The soil erosion also differed significantly between the different measures. The soil erosion of bare land, slope tillage, hedgerows with slope tillage, contour tillage, and straw mulching with conventional tillage decreased in that order. The sand-reduction effects of hedgerows with slope tillage, contour tillage, and straw mulching with conventional tillage all increase with $\mathrm{I}_{30}$, and their coefficients of variation and standard deviations decrease with increasing $\mathrm{I}_{30}$. Among soil and water conservation measures, straw mulching with conventional tillage has the most significant sediment-reduction benefits and the lowest coefficient of variation.

The MWDs of eroded sediment decrease under different treatments in the following order: bare land, slope tillage, hedgerows with slope tillage, contour tillage, and straw mulching with conventional tillage. Soil and water conservation measures can increase the fine sand content and reduce the coarse sand content. However, only the straw mulching with conventional tillage can significantly reduce the MWD of eroded sediment particles, relative to the slope farming.

Author Contributions: X.C. conceived and designed the study and conducted the experiments. X.C. and Z.L. conducted the data analysis and wrote the paper. L.Z. participated in the field investigation. Z.Z. contributed to improving the paper. All authors have read and agreed to the published version of the manuscript.

Funding: This research was supported by the National Key Research and Development Program of China (2017YFC0505405), the Water Conservancy Technology Project of Jiangxi Province (201921YBKT23) and the Science and Technology Department of Jiangxi Province (20181BBG78077).

Acknowledgments: The authors acknowledge the invaluable support for field and laboratory work from Xu Mingze, Zhao Shucheng, and Liu Jinshui.

Conflicts of Interest: The authors declare no conflicts of interest. 


\section{References}

1. Food and Agriculture Organisation of the United Nations. Status of the World's Soil Resources (SWSR)—Main Report; FAO: Rome, Italy, 2015; Volume 650.

2. Borrelli, P.; Robinson, D.A.; Fleischer, L.R.; Lugato, E.; Ballabio, C.; Alewell, C.; Meusburger, K.; Modugno, S.; Schütt, B.; Ferro, V.; et al. An assessment of the global impact of 21st century land use change on soil erosion. Nat. Commun. 2017, 8. [CrossRef] [PubMed]

3. Xiong, M.Q.; Sun, R.H.; Chen, L.D. Effects of soil conservation techniques on water erosion control: A global analysis. Sci. Total Environ. 2018, 645, 753-760. [CrossRef] [PubMed]

4. Frankl, A.; Prêtre, V.; Nyssen, J.; Salvador, P.G. The success of recent land management efforts to reduce soil erosion in northern France. Geomorphology 2017, 303, 84-93. [CrossRef]

5. Sadeghi, S.H.R.; Gholami, L.; Homaee, M.; Darvishan, A.K. Reducing sediment concentration and soil loss using organic and inorganic amendments at plot scale. Solid Earth 2015, 6, 445-455. [CrossRef]

6. Shen, H.O.; Wen, L.L.; He, Y.F.; Hu, W.; Li, H.L.; Che, X.C.; Li, X. Rainfall and inflow effects on soil erosion for hillslopes dominated by sheet erosion or rill erosion in the Chinese Mollisol region. J. Mt. Sci. 2018, 15, 2182-2191. [CrossRef]

7. Ng, S.L.; Cai, Q.G.; Ding, S.W.; Chau, K.C.; Qin, J. Effects of contour hedgerows on water and soil conservation, crop productivity and nutrient budget for slope farmland in the Three Gorges Region (TGR) of China. Agrofor. Syst. 2008, 74, 279-291. [CrossRef]

8. Pelt, R.S.V.; Hushmurodov, S.X.; Baumhardt, R.L.; Chappell, A.; Nearing, M.A.; Polyakov, V.O. The reduction of partitioned wind and water erosion by conservation agriculture. Catena 2017, 148, 160-167. [CrossRef]

9. Zhao, Q.G.; Huang, G.Q.; Ma, Y.Q. The problems in red soil ecosystem in southern of China and its countermeasures. Acta Ecol. Sin. 2013, 33, 7615-7622. [CrossRef]

10. Qian, J.; Zhang, L.P.; Wang, W.Y. The relationship between soil aggregates and eroded sediments from sloping vegetated red soils of South China. Acta Ecol. Sin. 2018, 38, 1590-1599. [CrossRef]

11. Yang, F.T.; Liu, J.Y.; Zhuang, D.F.; Hu, Y.F. The Preliminarily Study on the Ecological Environment Effects of Land-use Change in Red Earth Hilly Area in Southeast China. Prog. Geogr. 2004, 23, 43-55. [CrossRef]

12. Liu, H.H.; Zhang, T.Y.; Liu, B.Y.; Liu, G.; Wilson, G.V. Effects of gully erosion and gully filling on soil depth and crop production in the black soil erosion, northeast China. Environ. Earth Sci. 2013, 68, 1723-1732. [CrossRef]

13. Asadi, H.; Moussavi, A.; Ghadiri, H.; Rose, C.W. Flow-driven soil erosion processes and the size selectivity of sediment. J. Hydrol. 2011, 406, 73-81. [CrossRef]

14. Xu, Q.X.; Wu, P.; Dai, J.F.; Wang, T.W.; Li, X.Z.; Cai, C.F.; Shi, Z.H. The effects of rainfall regimes and terracing on runoff and erosion in the Three Gorges area, China. Environ. Sci. Pollut. Res. 2018, 25, 9474-9484. [CrossRef]

15. Wei, W.; Chen, L.; Fu, B.; Huang, Z.L.; Wu, D.P.; Gui, L. The effect of land uses and rainfall regimes on runoff and soil erosion in the semi-arid loess hilly area, China. J. Hydrol. 2007, 335, 247-258. [CrossRef]

16. Shi, D.M.; Lu, X.P.; Jiang, G.Y. Simulation on simple algorithm of rainfall erosivity in purple hilly area. Trans. Chin. Soc. Agric. Eng. 2010, 26, 126-132. [CrossRef]

17. Oliveira, P.T.S.; Wendland, E.; Nearing, M.A. Rainfall erosivity in Brazil: A review. Catena 2013, 100, $139-147$. [CrossRef]

18. Zheng, H.; Ou-Yang, Z.Y.; Wang, X.K.; Miao, H.; Zhao, T.Q.; Peng, B.T. Effects of forest restoration types on soil quality in red soil eroded region, Southern China. Acta Ecol. Sin. 2004, 24, 1994-2002. [CrossRef]

19. Xu, X.L.; Ma, K.M.; Fu, B.J.; Liu, X.C.; Huang, Y. Research review of the relationship between vegetation and soil loss. Acta Ecol. Sin. 2006, 26, 3137-3143. [CrossRef]

20. Michaelides, K.; Lister, D.; Wainwright, J.; Parsons, A.J. Vegetation controls on small-scale runoff and erosion dynamics in a degrading dryland environment. Hydrol. Process. 2009, 23, 1617-1630. [CrossRef]

21. Zanders, J.M. Road sediment: Characterization and implications for the performance of vegetated strips for treating road run-off. Sci. Total Environ. 2005, 339, 41-47. [CrossRef]

22. Jiang, F.S.; Huang, Y.H.; Zhong, B.L.; Yue, H. Effects of different measures on biomass and productivity in eroded red-soil region. Bull. Soil Water Conserv. 2009, 29, 12-16. [CrossRef]

23. Cao, X. Soil and Water Conservation Effect of Different Tillage Measures on Sloping Farmland in the Loess Plateau; Northwest A\&F University: Shaanxi, China, 2017. 
24. Kachanoski, R.G.; Lobb, D.A. Modelling tillage erosion in the topographically complex landscapes. Soil Till. Res. 1999, 51, 189-209. [CrossRef]

25. Wang, Z.L.; Shao, M.A.; Lei, T.W. Spatial patterns of tillage erosion and its contribution to total erosion in loess region of China. Acta Ecol. Sin. 2003, 1328-1335. [CrossRef]

26. Benites, J.R.; Derpsch, R.M.; Garry, D. Current Status and Future Growth Potential of Conservation Agriculture in the World Context. ISTROC 2003, 16, 120-128.

27. Borresen, T.; Riley, H. The need and potential for conservation tillage in Norway. ISTROC Aust. 2003, 1, 190-195.

28. Unger, P.W.; Vigil, M.F. Cover crop effects on soil water relationships. J. Soil Water Conserv. 1998, 53, $200-207$.

29. Wang, Z.G.; Wei, Z.Y. Study on sloping field erosion under simulated rainfall on loess broken plateau. J. Soil Erosion. Soil Water Conserv. 1995, 9, 51-57. [CrossRef]

30. Vol, N. Corn residue cover on the soil surface after planting for various tillage and planting systems. J. Soil Water Conserv. 1995, 50, 399-404.

31. Hairsine, P.B.; Sander, G.C.; Rose, C.W.; Parlange, J.Y.; Hogarth, W.L.; Lisle, I.; Rouhipour, H. Unsteady soil erosion due to rainfall impact: A model of sediment sorting on the hillslope. J. Hydrol. 1999, 220, 115-128. [CrossRef]

32. Issa, O.M.; Bissonnais, Y.L.; Planchon, O.; Favis-Mortlock, D. Soil detachment and transport on field and laboratory scale interrill areas: Erosion processes and the size selectivity of eroded sediment. Earth Surf. Proc. Land. 2006, 31, 929-939. [CrossRef]

33. Zhang, G.H.; Wang, L.L.; Li, G.; Tang, K.M.; Cao, Y. Relationship between sediment particle size and transport coefficient on steep slopes. ASABE 2011, 54, 869-874. [CrossRef]

34. Warrington, D.N.; Mamedov, A.I.; Bhardwaj, A.K.; Levy, G.J. Primary particle size distribution of eroded material affected by degree of aggregate slaking and seal development. Eur. J. Soil Sci. 2009, 60, 84-93. [CrossRef]

35. Berger, C.; Schulze, M.; Rieke-Zapp, D.; Schlunegger, F. Rill development and soil erosion: A laboratory study of slope and rainfall intensity. Earth Surf. Proc. Land. 2010, 35, 1456-1467. [CrossRef]

36. Wu, X.L.; Wei, Y.J.; Li, Z.X.; Cai, C.F.; Yang, W. Composition of sediments of erosion from different red soil slopes in subtropical area. Acta Pedol. Sin. 2014, 51, 1223-1233. [CrossRef]

37. Zhang, X.C.; Shao, M.A. Enrichment of organic matter and nitrogen in eroded bedloads. Chinese. J. Appl. Ecol. 2001, 12, 541-544. [CrossRef]

38. Peng, L.; Wang, J.Z.; Yu, C.Z. Nutrient losses in soils on Loess Plateau. Pedosphere 1995, 5, 83-92.

39. Asadi, H.; Ghadiri, H.; Rose, C.W.; Rouhipour, H. Interrill soil erosion processes and their interaction on low slopes. Earth Surf. Proc. Land. 2007, 32, 711-724. [CrossRef]

40. Tang, S.S.; Gao, H.D.; Li, Z.B.; Ren, Z.P.; Zhang, H.; Su, Y.; Zhi, Z. Characteristics of particle separation of erosion sediment in slop surface covered with sand. Trans. Chin. Soc. Agric. Eng. 2017, 33, 133-138. [CrossRef]

41. Qiu, Y.; Wang, X.; Li, D.L.; Wang, Y.F. Slope cultivated land rainfall runoff and sediment mechanical composition in different tillage patterns. J. Soil Water Conserv. 2012, 26, 62-65. [CrossRef]

42. Li, L.; Li, S.J.; Zhang, H.L.; Chen, F. Study on Soil C Pool Management Index of Conversation Tillage. J. Soil Water Conserv. 2006, 20, 106-109. [CrossRef]

43. Zhou, Z.D.; Cheng, J.H.; Yang, F.; Xiang, Y.M.; Dai, J.J. Influence of Vegetation Density on Size-selectivity of Sediments Eroded by Overland Flow on Northern Earth-rock Mountainous Area. J. Soil Water Conserv. 2016, 96-102. [CrossRef]

44. Zhou, D.Z. Impact of Herbaceous Plant on Size Selectivity of Erosion Process in North Earth-Rock Mountainous Area; Beijing Forestry University: Beijing, China, 2016.

45. Liang, J.Z. Characteristics of soil and water erosion on the slopes with different vegetation patterns in red soil region of Southern China. Res. Soil Water Conserv. 2015, 22, 95-99. [CrossRef]

46. Zhang, Q.Q.; Chen, Z.Q.; Chen, Z.B.; Ma, Q.Y. Characteristics of slope runoff and sediment yield and Rees migration under different soil and water conservation measures in a typical red soil region of Southern China. J. Soil Water Conserv. 2018, 32, 46-53. [CrossRef]

47. Wang, L.Y.; Nie, X.F.; Zuo, J.C.; Liu, Z.; Zheng, H.J. Effect of growth periods on nitrogen loss in runoff of peanut land on dry slope of red soil. J. Soil Water Conserv. 2019, 33. [CrossRef] 
48. Chen, X.A.; Yang, J.; Zheng, T.H.; Zhang, J. Sediment, runoff, nitrogen and phosphorus losses of sloping cropland of quaternary red soil in northern Jiangxi. Trans. Chin. Soc. Agric. Eng. 2015, 31, 162-167. [CrossRef]

49. Meng, Q.Y.; Zou, H.T.; Han, Y.Y.; Zhang, C.F. Effects of straw application rates on soil aggregates, soil organic carbon content and maize yield. Trans. Chin. Soc. Agric. Eng. 2019, 35, 119-125. [CrossRef]

50. Zhang, H.; Li, P.; Lu, K.X.; Ren, Z.P.; Wang, T. Effects of Freezing and Thawing on Soil Erosion and Sediment Particle Size Fractionation. Acta Pedol. Sin. 2017, 54, 836-843. [CrossRef]

51. Le Bissonnais, Y. Aggregate Stability and Assessment of Soil Crustability and Erodibility: I. Theory and Methodology. Eur. J. Soil Sci. 1996, 47, 425-437. [CrossRef]

52. Ma, W.; Li, Z.; Ding, K.; Huang, J.Q.; Nie, X.D.; Zeng, G.; Wang, S.; Liu, G. Effect of soil erosion on dissolved organic carbon redistribution in subtropical red soil under rainfall simulation. Geomorphology 2014, 226, 217-225. [CrossRef]

53. Meshesha, D.T.; Tsunekawa, A.; Tsubo, M.; Haregeweyn, N.; Tegegne, F. Evaluation of kinetic energy and erosivity potential of simulated rainfall using Laser Precipitation Monitor. Catena 2016, 137, 237-243. [CrossRef]

54. Yan, F.L.; Shi, Z.H.; Cai, C.F.; Li, Z.X. Effects of topsoil aggregate stability on soil erosion at hillslope on ultisoils. Acta Pedol. Sin. 2007, 44, 3-9. [CrossRef]

55. Wang, L.; Shi, Z.H.; Wang, J.; Fang, N.F.; Wu, G.L.; Zhang, H.Y. Rainfall kinetic energy controlling erosion processes and sediment sorting on steep hillslopes: A case study of clay loam soil from the Loess Plateau, China. J. Hydrol. 2014, 512, 168-176. [CrossRef]

56. Fang, N.F.; Shi, Z.H.; Li, L.; Guo, Z.L.; Liu, Q.J.; Ai, L. The effects of rainfall regimes and land use changes on runoff and soil loss in a small mountainous watershed. Catena 2012, 99, 1-8. [CrossRef]

57. Zhou, Y.W.; Dai, C.T.; Liu, Y.J.; Wang, T.W.; Li, Z.X.; Hu, Y.X. Effects of cultivation measures and rainfall intensities on the slope erosion in red soil sloping cropland. J. Soil Water Conserv. 2019, 33, 51-56. [CrossRef]

58. Madejón, E.; Murillo, J.M.; Moreno, F.; Lópezb, M.V.; Arrueb, J.L.; Alvaro-Fuentesb, J.; Cantero, C. Effect of long-term conservation tillage on soil biochemical properties in Mediterranean Spanish areas. Soil Till. Res. 2009, 105, 55-62. [CrossRef]

59. Ruiz-Colmenero, M.; Bienes, R.; Eldridge, D.J.; Marques, M.J. Vegetation cover reduces erosion and enhances soil organic carbon in a vineyard in the central Spain. Catena 2013, 104, 153-160. [CrossRef]

60. Preiti, G.; Romeo, M.; Bacchi, M.; Monti, M. Soil loss measure from Mediterranean arable cropping system: Effects of rotation and tillage system on C-factor. Soil Till. Res. 2017, 170, 85-93. [CrossRef]

61. Martínez-Menaa, M.; Carrillo-Lópeza, E.; Boix-Fayosa, C.; Almagrob, M.; García Francoc, N.; Díaz-Pereiraa, E.; Montoyaa, I.; de Vente, J. Long-term effectiveness of sustainable land management practices to control runoff, soil erosion, and nutrient loss and the role of rainfall intensity in Mediterranean rainfed agroecosystems. Catena 2020, 187, 104352. [CrossRef]

62. Liu, H.; Huang, Q. Adoption and continued use of contour cultivation in the highlands of southwest China. Ecol. Econ. 2013, 91, 28-37. [CrossRef]

63. Dai, C.T.; Liu, Y.J.; Wang, T.W.; Li, Z.X. Exploring optimal measures to reduce soil erosion and nutrient losses in southern China. Agric. Water Manag. 2018, 210, 41-48. [CrossRef]

64. Beuselinck, L. Characteristics of sediment deposits formed by intense rainfall events in small catchments in the Belgian Loam Belt. Geomorphology 2000, 32, 69-82. [CrossRef]

65. Dai, J.M.; Zha, X.; Huang, S.Y.; Chen, S.F.; Zhai, S.H.; Wang, L.Y.; Liu, C. Effects of Slope Gradients on Erosion Under Different Vegetation Coverage on Purple Slopes. J. Soil Water Conserv. 2017, 3, 33-38. [CrossRef]

66. Agata, N.; Giovanni, S.; Artemio, C.; Luciano, G. The Effect of Shallow Tillage on Soil Erosion in a Semi-Arid Vineyard. Agronomy 2019, 9, 257. [CrossRef]

67. Zheng, F.L.; Bian, F.; Lu, J.; Tan, C.; Xu, X.M. Effects of rainfall patterns on hillslope erosion with longitudinal ridge in typical black soil region of Northeast China. Trans. Chin. Soc. Agric. Eng. 2016, 47, 90-97. [CrossRef]

68. Wang, X.; Liu, Y.; Liu, Y.C.; Xin, Y.; Wang, X.H. The Sediment and Runoff Reduction Effect under the Different Soil and Water Conservation Measures in the Earth-rock Mountains. J. Shenyang Agric. Univ. 2014, 45, 86-92. [CrossRef]

69. Peng, X.D.; Dai, Q.H.; Li, C.L. Output mechanism of soil nutrients from karst slope farmland under simulated rainfall. Acta Ecol. Sin. 2018, 38, 624-634. [CrossRef] 
70. Lin, C.E.; Luo, C.Y.; Pang, L.Y.; Huang, J.J.; Fu, D.W.; Tu, S.H.; Pu, B. Effects of different cultivation and mulching methods on soil erosion and nutrient losses from a purple soil of sloping land. Acta Ecol. Sin. 2010, 30, 6091-6101. [CrossRef]

71. Pu, Y.L. Effect of Hedgerow-Crop Patterns on Controlling Nitrogen and Phosphorus Runoff and Evaluation of Comprehensive Ecological Benefits in Slope Farmland; Southwest University: Chongqing, China, 2013.

(C) 2020 by the authors. Licensee MDPI, Basel, Switzerland. This article is an open access article distributed under the terms and conditions of the Creative Commons Attribution (CC BY) license (http://creativecommons.org/licenses/by/4.0/). 